$\begin{array}{rr}\text { JURNAL } & \text { Volume } 14, \text { Nomor } 1, \text { Januari } 2018 \\ \text { FIT(1) PATOLOGI } & \text { Halaman } 15-22 \\ \text { I N D O N ES IA } & \text { DOI: } 10.14692 / \text { jfi.14.1.15 } \\ \text { ISSN: } 0215-7950 & \end{array}$

\title{
Metabolit Bakteri Endofit Asal Tanaman Kacang Tanah sebagai Penghambat Pertumbuhan Aspergillus flavus
}

\author{
Metabolites of Endophytic Bacteria Isolated from Peanut Plant as \\ Growth Inhibitor of Aspergillus flavus
}

\author{
Nela Zahara, Bonny Poernomo Wahyu Soekarno*, Abdul Munif \\ Institut Pertanian Bogor, Bogor 16680
}

\begin{abstract}
ABSTRAK
Kacang tanah (Arachis hypogeae) merupakan tanaman pangan penting di Indonesia dan konsumsinya di dalam negeri cenderung meningkat. Salah satu faktor pembatas kualitas benih kacang tanah yaitu adanya infeksi cendawan Aspergillus flavus. Penggunaan metabolit bakteri dapat dijadikan alternatif pengendalian yang efektif dan efisien. Penelitian ini bertujuan untuk mendapatkan bakteri endofit yang berpotensi sebagai agens pengendali hayati terhadap $A$. flavus. Tahapan penelitian terdiri atas isolasi $A$. flavus, isolasi bakteri endofit dari jaringan tanaman kacang tanah, uji hipersensitif, uji penghambatan terhadap A. flavus, ekstraksi dan uji metabolit bakteri endofit, uji perlakuan benih dengan senyawa metabolit dan identifikasi bakteri endofit. Berdasarkan hasil uji hipersensitif terdapat 37 bakteri endofit nonpatogenik terhadap tumbuhan. Hasil seleksi mendapatkan 3 bakteri endofit dengan penghambatan terbaik, yaitu BE2B2-1 (71.64\%), BE2B2-2 (69.05\%), dan BE2B2-5 (65.25\%). Identifikasi bakteri endofit berdasarkan perunutan DNA menunjukkan bahwa BE2B2-1, BE2B2-2, dan BE2B2-5 berturutturut adalah Enterobacter sp., Bacillus sp., dan Acinetobacter sp. Spesies Enterobacter sp. memiliki aktivitas antimikrob tertinggi terhadap A. flavus pada uji in vitro dengan daya hambat hingga $61.70 \%$, daya hambat infeksi hingga $77.22 \%$ dengan metode growing on test, dan peningkatan perkecambahan benih kacang tanah hingga $4.25 \%$. Hasil penelitian menunjukkan potensi metabolit dari mikrob endofit sebagai salah satu bagian strategi pengendalian $A$. flavus.
\end{abstract}

Kata kunci : agens pengendali hayati, antimikrob, perlakuan benih, uji hipersensitif

\section{ABSTRACT}

Peanut (Arachis hypogeae) is considered as important crop in Indonesia and domestic demands to peanut tend to increase recently. Infection of fungal seedborne, Aspergillus flavus, may downgrade peanut seed quality. Research was conducted to evaluate the application of secondary metabolite produced by endophytic bacteria for controlling A. flavus. The methodologies involved isolation A. flavus and endophytic bacteria from the plant tissue of peanut, hypersensitive test of endophytic bacteria, inhibition test of endophytic bacteria against $A$. flavus, extraction and examination of secondary metabolite from endophytic bacteria, seed treatment using extracted secondary metabolite, and molecular identification of the bacteria. Based on hypersensitive test, 37 isolates of endophytic bacteria were identified as non pathogenic. Further screening by dual culture test found 3 isolates with high inhibition activity, i.e. BE2B2-1 (71.64\%), BE2B2-2 (69.05\%), and BE2B2-5 (62.25\%). Molecular identification based on nucleotide sequencing of 16S rRNA showed that BE2B2-1, BE2B2-2, and BE2B2-5 were Enterobacter sp., Bacillus sp., and Acinetobacter sp., respectively. Metabolite from Enterobacter sp. has the highest

*Alamat penulis korespondensi: Departemen Proteksi Tanaman, Fakultas Pertanian, Institut Pertanian Bogor, Jalan Kamper, Kampus IPB Dramaga, Bogor 16680

Tel: 0251-8629364, Faks: 0251-8629362, surel: bonnypws@gmail.com 
antimicrobial activity (61.70\%) against $A$. flavus in in vitro test, highest infection inhibition (77.22\%) in growing-on test, and highest increasing of seed germination rate $(4.25 \%)$. This finding indicated the potential of secondary metabolites from endophyte bacteria to suppress infestation of A. flavus.

Key words: antimicrobe, biocontrol agent, hypersensitive test, seed treatment

\section{PENDAHULUAN}

Keberhasilan usaha tani suatu tanaman sangat ditentukan oleh kualitas benih karena dapat memengaruhi pertumbuhan dan produksi tanaman. Infeksi patogen pada benih kacang tanah dapat terjadi mulai dari lapangan, saat pengangkutan hingga penyimpanan. Ibiam dan Egwu (2011) menyatakan terdapat 10 spesies Aspergillus sp. yang menginfeksi kacang tanah dan ditemukan di lapangan maupun tempat penyimpanan benih, yaitu Aspergillus flavus, A. niger, A. tamari, A. terreus, A. fumigatus, $A$. nidulans dan $A$. culmoru.

Cendawan A. flavus merupakan cendawan yang penting dalam kerusakan benih. Hossain et al. (2013) melaporkan bahwa A. flavus juga menginfeksi benih tanaman hortikultura selain tanaman pangan, dan dapat menurunkan perkecambahan pada 11 benih sayuran. Kontaminasi aflatoksin dimulai dari infeksi di pertanaman dan terbawa benih ke tempat penyimpanan, kemudian menjadi sumber inokulum awal penyebab kontaminasi di gudang-gudang penyimpanan.

A. flavus dapat menghasilkan enzim amilase, selulose, amiloglukosidase dan mikotoksin. Mikotoksin yang dihasilkan ialah aflatoksin BI yang paling toksik karena bersifat karsinogenik, hepatotoksik, mutagenik bagi tanaman, manusia, mamalia, dan unggas (Dharmaputra et al. 2013).

Upaya untuk mengurangi resiko kerugian yang disebabkan A. flavus ialah dengan aplikasi fungisida sintetik, secara fisik dengan perendaman dalam air panas, dan radiasi. Meskipun demikian, alternatif pengendalian cendawan patogen terbawa benih yang efektif, efisien, ramah lingkungan, dan berkelanjutan masih perlu dikembangkan. Infeksi cendawan patogen pada benih dapat menimbulkan kerusakan fisik, perubahan biokimia yang mengganggu aktivitas fisiologis benih, menjadi inokulum penyakit pada tanaman dewasa dan menurunkan viabilitas. Penurunan viabilitas benih terjadi akibat cendawan terbawa benih dapat mengganggu enzim-enzim yang diperlukan dalam perkecambahan, membunuh embrio dan membusukkan benih secara total (Triana 2007).

Mikroba endofit secara alamiah menghasilkan auksin dan fitohormon. Beberapa isolat bakteri mampu menghasilkan fitohormon dan juga berperan sebagai pelarut fosfat, penambat nitrogen dan pelarut kalium (Sukmadi 2013). Arios et al. (2014) melaporkan bahwa bakteri endofit yang diisolasi dari tanaman kacang tanah mampu menghambat pertumbuhan Sclerotium sp., mampu meningkatkan tinggi, jumlah daun, dan berat kering kecambah kacang tanah. Penelitian ini bertujuan untuk menentukan potensi metabolit bakteri endofit dari kacang tanah untuk menghambat pertumbuhan cendawan A. flavus pada kacang tanah.

\section{BAHAN DAN METODE}

\section{Isolasi Cendawan $\boldsymbol{A}$. flavus}

Isolasi cendawan $A$. flavus dilakukan dengan metode blotter test (ISTA 1996). Cendawan yang diduga $A$. flavus diisolasi ke dalam medium agar dekstrosa kentang (ADK) kemudian diamati dibawah mikroskop dan diidentifikasi secara morfologi menggunakan buku identifikasi Barnett et al. (1998).

\section{Isolasi Bakteri Endofit}

Bakteri endofit diisolasi dari bagian akar, batang, daun, dan benih tanaman kacang tanah yang sehat mengikuti metode Munif et al. (2012) dengan modifikasi pada tahapan sterilisasi permukaan. Sebanyak $0.1 \mathrm{~mL}$ ekstrak dari pengenceran $10^{-1}, 10^{-2}$, dan $10^{-3}$ disebar pada medium tryptic soy agar 20\% (TSA: $17 \mathrm{~g}$ pancreatic digest of casein, 
$3 \mathrm{~g}$ papaic digest of soyabean meal, $5 \mathrm{~g}$ sodium cloride, $2.5 \mathrm{~g}$ dipotassium hydrogen phosphate, $2.5 \mathrm{~g}$ dextrose) dan diinkubasi selama 1-2 hari pada suhu ruang $\left(27^{\circ} \mathrm{C}\right)$. Koloni bakteri yang tumbuh dimurnikan pada medium TSA $100 \%$.

\section{Uji Hipersensitif}

Sebanyak $5 \mathrm{~mL}$ bakteri endofit ditumbuhkan pada medium tryptic soy broth (TSB) dalam tabung. Selanjutnya, suspensi dengan kerapatan $10^{8} \mathrm{cfu} \mathrm{mL}^{-1}$ dikocok dengan kecepatan 100 rpm selama 24 jam. Suspensi bakteri diambil sebanyak $1 \mathrm{~mL}$ dan disuntikkan pada daun tembakau varietas Pranca. Ada tidaknya gejala nekrosis pada daun tembakau diamati setelah 48 jam pada suhu $27^{\circ} \mathrm{C}$ (Klement dan Goodman 1967).

\section{Uji Penghambatan Bakteri Endofit terhadap $A$. flavus}

Uji penghambatan bakteri endofit terhadap A. flavus dilakukan dengan teknik kultur ganda pada medium ADK. Bakteri endofit uji digoreskan pada kedua sisi medium dengan jarak $2.5 \mathrm{~cm}$ dari tepi. Pengamatan dilakukan terhadap zona hambatan yang dihasilkan pada hari ke-7 dan persentase penghambatan dihitung menggunakan rumus:

$\%$ perkecambahan $=\frac{\mathrm{r} 1-\mathrm{r} 2}{\mathrm{r} 2} \times 100 \%$, dengan

r1, jari-jari A.flavus yang tumbuh berlawanan dengan endofit; r2, jari-jari A.flavus yang tumbuh ke arah endofit.

Ekstraksi dan Uji Metabolit Bakteri Endofit

Berdasarkan hasil uji penghambatan terhadap A. flavus, dipilih 3 isolat bakteri endofit yang memiliki daya hambat paling tinggi. Isolat bakteri endofit yang terpilih ditumbuhkan pada $200 \mathrm{~mL}$ medium TSB dalam erlenmeyer kemudian dikocok dengan kecepatan $150 \mathrm{rpm}$. Kultur bakteri endofit selanjutnya disentrifugasi pada kecepatan 5000 rpm selama 20 menit untuk memisahkan supernatan dari massa selnya. Supernatan disaring menggunakan millipore syringe filter $0.2 \mu \mathrm{m}$ dan digunakan sebagai ekstrak kasar senyawa metabolit (Elita et al. 2013). Metabolit bakteri endofit dari masing-masing bakteri diencerkan dalam medium ADK (konsentrasi 5\%, 10\%, 15\%, 20\%, dan 30\%). Pada setiap konsentrasi dibiakkan A. flavus berdiameter $0.5 \mathrm{~cm}$ dan sebagai kontrol digunakan medium ADK tanpa campuran metabolit. Inkubasi cendawan dilakukan pada suhu ruang $\left(27-30{ }^{\circ} \mathrm{C}\right)$ selama 7 hari. Daya hambat metabolit bakteri endofit terhadap $A$. flavus dihitung menggunakan rumus:

$$
\text { Daya hambat }=\frac{\mathrm{D} 1-\mathrm{D} 2}{\mathrm{D} 1} \times 100 \% \text {, dengan }
$$

D1, diameter Affavus kontrol (cm); D2, diameter A.flavus pada perlakuan (cm).

\section{Uji Perlakuan Benih dengan Senyawa Metabolit}

Benih kacang tanah sebanyak 100 biji direndam selama 20 menit pada metabolit bakteri endofit (konsentrasi 5\%, 10\%, 15\%, $20 \%$, dan 30\%) dan akuades steril sebagai kontrol. Pengujian daya hambat infeksi dan daya berkecambah benih dilakukan dengan menggunakan metode blotter test pada kertas merang dan metode growing on test pada medium tanah. Daya hambat infeksi cendawan A. flavus dihitung dengan rumus:

Daya hambat infeksi $=\frac{\mathrm{N} 1-\mathrm{N} 2}{\mathrm{~N} 1} \times 100 \%$, dengan

$\mathrm{N} 1$, jumlah tanaman terinfeksi pada kontrol; $\mathrm{N} 2$, jumlah tanaman terinfeksi pada perlakuan metabolit. Persentase daya kecambah benih dihitung menggunakan rumus:

$$
\text { Daya kecambah }=\frac{\mathrm{n}}{\mathrm{N}} \times 100 \% \text {, dengan }
$$

$\mathrm{n}$, jumlah benih berkecambah normal; $\mathrm{N}$, total keseluruhan benih.

\section{Identifikasi Molekuler Bakteri Endofit}

Isolasi DNA diawali dengan penyiapan kultur bakteri pada medium cair (nutrient broth/ trypticase soya broth/luria-bertani broth) dan diinkubasi selama 24 jam pada shaker dengan kecepatan $100 \mathrm{rpm}$. Sebanyak $1.5 \mathrm{~mL}$ biakan bakteri tersebut dimasukkan ke dalam tabung mikro kemudian dipeletkan dan disentrifugasi pada kecepatan $10000 \mathrm{rpm}$ selama 5 menit.

Pelet bakteri disuspensikan dengan $250 \mu \mathrm{L}$ bufer TE mengandung $5 \mathrm{mg} \mathrm{mL} \mathrm{mL}^{-1}$ lysozim, kemudian diinkubasikan pada suhu $37{ }^{\circ} \mathrm{C}$ 
selama 30 menit pada shaker water bath. Sebanyak $50 \mu \mathrm{L}$ SDS 10\% ditambahkan ke dalam suspensi, diaduk dengan membolakbalikkan tabung mikro, diinkubasi kembali pada suhu $37^{\circ} \mathrm{C}$ selama 60 menit pada shaker water bath. Sebanyak $65 \mu \mathrm{L} \mathrm{NaCl} 5 \mathrm{M}$ dan $80 \mu \mathrm{L}$ CTAB-NaCl ditambahkan kedalam suspensi lalu diinkubasi pada suhu $65{ }^{\circ} \mathrm{C}$ selama 20 menit pada shaker water bath. Setelahitu, sebanyak $450 \mu$ Lkloroform:isoamil alkohol atau C:1 (24:1) ditambahkan ke dalam suspensi, kemudian dikocok selama 30 menit. Selanjutnya suspensi disentrifugasi pada kecepatan 11000 rpm selama 20 menit hingga terbentuk tiga lapisan. Larutan epifase diambil dan dipindahkan ke dalam tabung mikro dan dipresipitasi dengan menambahkan $400 \mu \mathrm{L}$ larutan isopropanol dingin $\left(-20^{\circ} \mathrm{C}\right)$, kemudian diinkubasi minimal 30 menit pada suhu $-20^{\circ} \mathrm{C}$.

Setelah presipitasi, DNA disentrifugasi pada kecepatan 12000 rpm selama 20 menit pada suhu $4{ }^{\circ} \mathrm{C}$. Pelet yang terbentuk dicuci menggunakan $800 \mu \mathrm{L}$ etanol dingin $70 \%$ $\left(-20{ }^{\circ} \mathrm{C}\right)$ dan disentrifugasi selama 2 menit dengan kecepatan $12000 \mathrm{rpm}$ pada suhu $4{ }^{\circ} \mathrm{C}$. Pelet DNA kemudian dilarutkan dengan bufer TE. Selanjutnya, suspensi DNA disimpan pada suhu $-20{ }^{\circ} \mathrm{C}$. Amplifikasi pita DNA bakteri dilakukan menggunakan primer universal bakteri, yaitu primer forward $27 \mathrm{~F}$ (5'-TACGGYTACCTTGTTACGACTT-3') dan primer reverse $1492 \mathrm{R}$ (5'-AGAGTTTG ATCCTGGCTCAG-3') dan dilanjutkan dengan perunutan DNAdi First Base, Malaysia.

\section{Rancangan Percobaan dan Analisis Data}

Percobaan disusun dalam rancangan acak lengkap faktorial dengan 2 faktor, yaitu isolat bakteri endofit (3 isolat) dan konsentrasi senyawa metabolit $(5 \%, 10 \%, 15 \%, 20 \%$, dan $30 \%$ ), serta diulang sebanyak 8 ulangan. Data dianalisis dengan program SAS 9.1. Perlakuan yang berpengaruh nyata diuji lanjut dengan uji selang berganda Duncan (DMRT) pada taraf 5\%.

\section{HASIL}

Cendawan $A$. flavus yang diisolasi dengan metode blotter test memiliki morfologi koloni agak kasar, berwarna kuning kehijauan, kemudian dikonfirmasi setelah dilakukan pengamatan secara makroskopis dan mikroskopis (Gambar 1). Hasil penelitian diperoleh 191 isolat dari bagian akar, batang, daun dan benih tanaman kacang tanah. Sebanyak 52 isolat bakteri berasal dari akar, 67 isolat asal batang, 64 isolat asal daun, dan 8 isolat asal benih kacang tanah. Hasil uji reaksi hipersensitif diperoleh 37 bakteri endofit bersifat nonpatogenik.

\section{Daya Hambat Bakteri Endofit terhadap $\boldsymbol{A}$. flavus}

Pada hari ke-7, bakteri endofit memiliki daya hambat lebih dari 40\% (Tabel 1). Hasil penelitian mendapatkan 3 isolat bakteri endofit yang memiliki daya hambat terbaik, yaitu BE2B2-1 (71.64\%), BE2B2-2 (69.05\%), dan BE2B2-5 (65.25\%) (Gambar 2).

\section{Kemampuan Metabolit Bakteri Endofit dalam Menghambat Pertumbuhan Cendawan Patogen $A$. flavus}

Kemampuan metabolit bakteri endofit dalam menghambat pertumbuhan A. flavus berbeda pada setiap konsentrasi. Isolat BE2B2-1 pada konsentrasi 15\% memiliki daya hambat tertinggi $(61.70 \%)$, isolat BE2B2-2 pada konsentrasi $30 \%$ daya hambatnya sebesar $46.68 \%$ dan isolat BE2B2-5 pada konsentrasi $15 \%$ memiliki daya hambat tertinggi sebesar $46.10 \%$ (Tabel 2) (Gambar 3).

\section{Pengaruh Metabolit Bakteri Endofit} terhadap Daya Hambat Infeksi Cendawan A.flavus dan Daya Kecambah Kacang Tanah

Hasil uji metabolit bakteri endofit terhadap infeksi cendawan patogen A. flavus pada benih menunjukkan tidak berbeda nyata (Tabel 3). Metabolit bakteri endofit BE2B2-1, BE2B2-2, dan BE2B2-5 mampu menghambat infeksi $A$. flavus, dan mempertahankan daya kecambah serta tinggi tanaman dibandingkan dengan kontrol pada uji blotter test dan growing on test.

\section{Identifikasi Molekuler Bakteri Endofit}

Identifikasi dan perunutan DNA menunjukkan bahwa isolat BE2B2-1 identik 94\% 


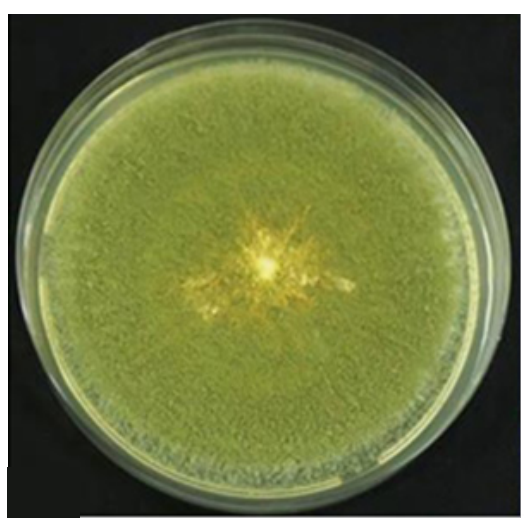

Miselium A. flavus

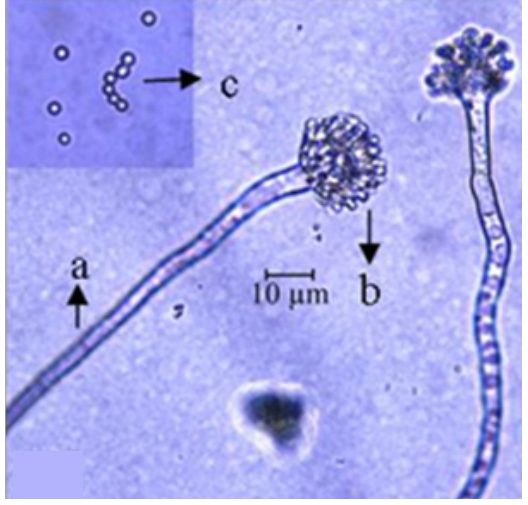

Karakteristik A. flavus

Gambar 1 Karakter morfologi dan mikroskopis A. flavus. a, Konidiofor; b, Konidium pada kolumela; dan c, Konidium.

Tabel 1 Daya hambat bakteri endofit terhadap pertumbuhan A. flavus.

\begin{tabular}{lcccc}
\hline Isolat & $\begin{array}{c}\text { Daya hambat } \\
(\%)\end{array}$ & & Isolat & $\begin{array}{c}\text { Daya hambat } \\
(\%)\end{array}$ \\
\cline { 1 - 2 } BE2B2-1 & $71.64^{*}$ & & BE2D1-3 & 54.78 \\
BE2B2-2 & $69.05^{*}$ & & BE2D1-7 & 54.16 \\
BE2B2-5 & $65.26^{*}$ & & BE2D1-16 & 53.20 \\
BE2B2-18 & 60.58 & & BE2D1-17 & 52.48 \\
BE2B2-12 & 60.06 & & BE2D1-11 & 51.87 \\
BE2D1-13 & 58.75 & & BE2D3-2 & 51.68 \\
BE2B2-11 & 57.10 & & BE2D1-8 & 50.43 \\
BE2D1-18 & 56.80 & & BE2D2-5 & 50.11 \\
BE2DI-10 & 56.64 & & BE2D1-9 & 50.06 \\
BE2B2-23 & 56.53 & & BE2D1-2 & 49.72 \\
BE2D1-12 & 56.52 & & BE2B2-4 & 48.81 \\
BE2A1-1 & 55.98 & & BE2D1-5 & 48.52 \\
BE2D1-15 & 55.90 & & BE2D2-7 & 48.17 \\
BE2D2-4 & 55.69 & & BE2B2-10 & 47.91 \\
BE2D1-14 & 55.15 & & BE2D1-4 & 47.22 \\
BE2B2-13 & 55.05 & & BE2D1-19 & 46.07 \\
BE2D2-2 & 54.99 & & BE2B2-3 & - \\
BE2D1-1 & 54.97 & & KONTROL & 43.98 \\
BE2B2-7 & 54.87 & &
\end{tabular}

* Isolat bakteri endofit yang memiliki daya hambat terbaik terhadap A. flavus

dengan Enterobacter sp.. Bakeri endofit isolat BE2B2-2 dan BE2B2-5 diidentifikasi sebagai Bacillus sp., dan Acinetobacter sp. dengan homologi berturut-turut $98 \%$ dan $97 \%$ (Tabel 4 ).

\section{PEMBAHASAN}

Bakteri endofit yang telah diisolasi dari bagian akar, batang, daun, dan benih tanaman kacang tanah memiliki potensi untuk dikembangkan sebagai agens hayati dengan memanfaatkan senyawa metabolit untuk menghambat pertumbuhan $A$. flavus pada kacang tanah. Bakteri endofit merupakan bakteri yang mengolonisasi tumbuhan secara internal tanpa merugikan tumbuhan dan umumnya diisolasi dari jaringan internal tumbuhan secara langsung melalui sentrifugasi atau secara tidak langsung melalui sterilisasi permukaan (Hallmann et al. 1997).

Hasil pengujian daya hambat bakteri endofit diperoleh isolat-isolat potensial yang 


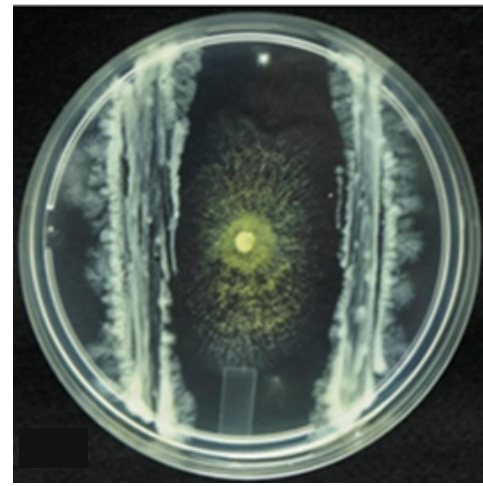

a

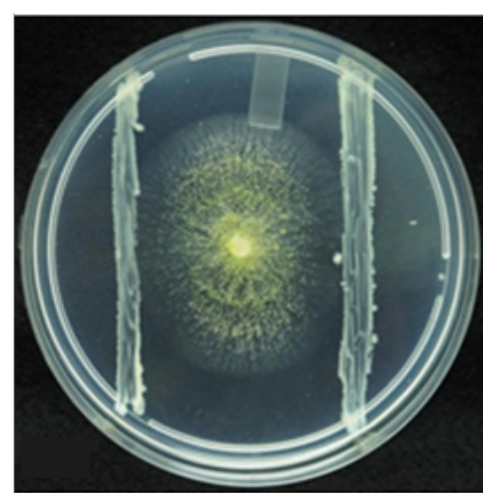

b

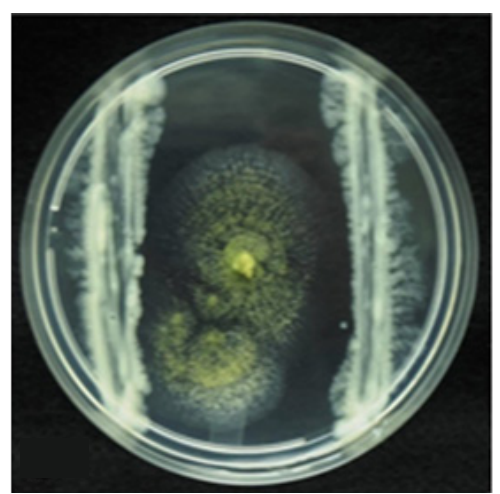

c

Gambar 2 Uji kultur ganda isolat bakteri endofit terhadap A. flavus. A, BE2B2-1; B, BE2B2-2; dan C, BE2B2-5

Tabel 2 Kemampuan penghambatan beberapa konsentrasi metabolit bakteri endofit terhadap A. flavus

\begin{tabular}{lccccc}
\hline \multirow{2}{*}{ Perlakuan } & \multicolumn{5}{c}{ Konsentrasi (\%) } \\
\cline { 2 - 6 } & 5 & 10 & 15 & 20 & 30 \\
\hline BE2B2-1 & $39.77 \mathrm{c}$ & $49.78 \mathrm{~b}$ & $61.70 \mathrm{a}$ & $44.62 \mathrm{bc}$ & $31.81 \mathrm{~d}$ \\
BE2B2-2 & $20.33 \mathrm{c}$ & $22.09 \mathrm{c}$ & $23.57 \mathrm{c}$ & $30.19 \mathrm{~b}$ & $46.68 \mathrm{a}$ \\
BE2B2-5 & $18.85 \mathrm{~d}$ & $21.79 \mathrm{c}$ & $46.10 \mathrm{a}$ & $34.02 \mathrm{~b}$ & $34.90 \mathrm{~b}$ \\
\hline
\end{tabular}

Angka pada kolom yang sama dan diikuti huruf yang sama menunjukkan tidak berbeda nyata menurut uji Duncan pada $\alpha 5 \%$.

$\mathrm{a}$

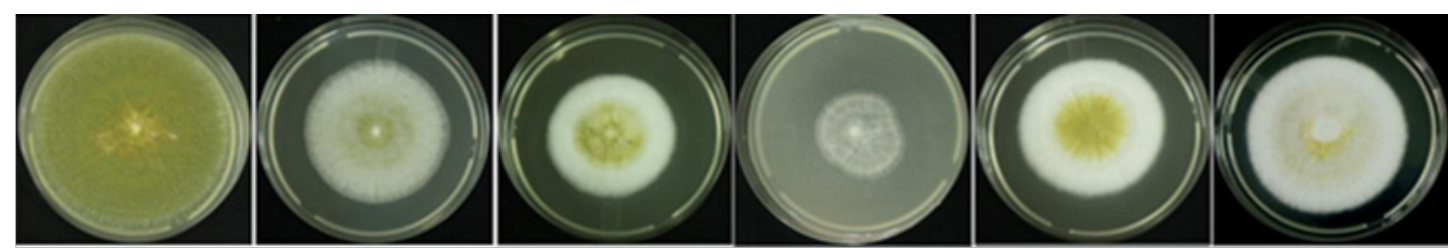

b
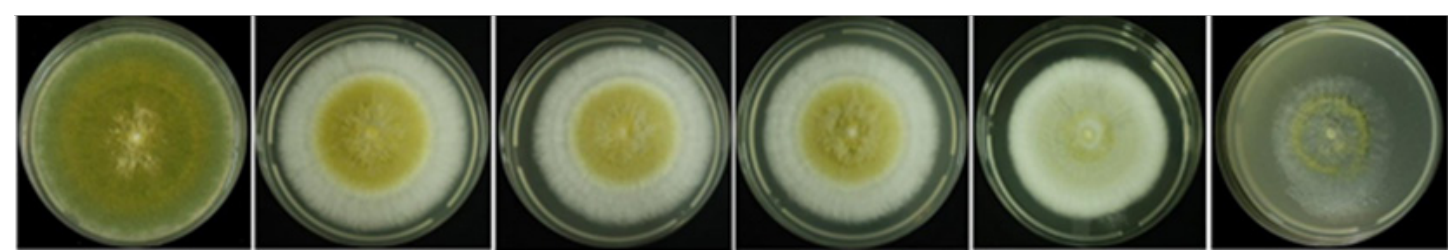

C

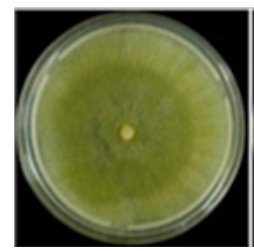

Konnrol

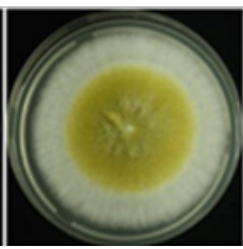

$5 \%$

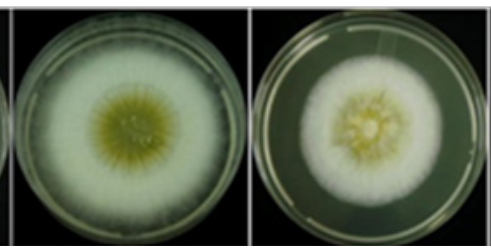

$10 \%$

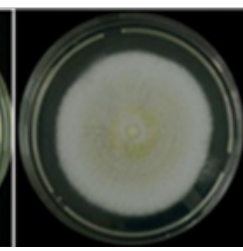

$20 \%$

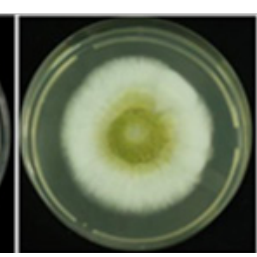

$30 \%$

Gambar 3 Pengaruh konsentrasi metabolit bakteri endofit terhadap pertumbuhan A. flavus. a, BE2B2-1; b, BE2B2-2; dan c, BE2B2-5.

memiliki daya hambat terhadap pertumbuhan A. flavus. Ikeda et al. (2010) menyatakan bahwa mekanisme kerja bakteri endofit ialah menghasilkan senyawa antimikrob untuk melawan patogen, menghasilkan zat pengatur tumbuh, memfiksasi nitrogen dan memobilisasi fosfat yang berperan dalam memacu dan memperkuat pertumbuhan serta ketahanan tanaman. Abidin et al. (2015) menjelaskan bahwa hasil uji in vitro terhadap bakteri Bacillus sp. menunjukan bahwa bakteri tesebut memiliki mekanisme antibiosis terhadap 
Tabel 3 Daya hambat (\%) metabolit terhadap infeksi A. flavus, perkecambahan (\%) dan pertumbuhan tanaman kacang tanah

\begin{tabular}{lcccccccc}
\hline Perlakuan & \multicolumn{3}{c}{ Blotter test } & & \multicolumn{3}{c}{ Growing on test } \\
\cline { 2 - 4 } \cline { 7 - 8 } & $\begin{array}{r}\text { DHI } \\
(\%)\end{array}$ & $\begin{array}{c}\text { DB } \\
(\%)\end{array}$ & $\begin{array}{c}\text { TN } \\
(\mathrm{cm})\end{array}$ & & $\begin{array}{c}\text { DHI } \\
(\%)\end{array}$ & $\begin{array}{c}\text { DB } \\
(\%)\end{array}$ & $\begin{array}{c}\text { TN } \\
(\mathrm{cm})\end{array}$ \\
\hline Kontrol & 0.00 & 92 & 10.27 & & 0.00 & 94 & 28.08 \\
BE2B2-1 & 30.43 & 95 & 10.51 & & 77.22 & 98 & 28.65 \\
BE2B2-2 & 52.17 & 96 & 11.05 & & 66.67 & 98 & 28.25 \\
BE2B2-5 & 69.57 & 96 & 10.82 & & 44.44 & 96 & 28.90 \\
\hline
\end{tabular}

Kontrol, benih direndam akuades; DHI, daya hambat infeksi; DB, daya kecambah; TN, tinggi tanaman.

Tabel 4 Hasil identifikasi molekuler bakteri endofit

\begin{tabular}{|c|c|c|c|}
\hline Isolat Asal & Identitas & Kode Aksesi & $\begin{array}{l}\text { Homologi } \\
(\%)\end{array}$ \\
\hline BE2B2-1 & Enterobacter sp. R4-368, complete genom & СР005991.1 & 94 \\
\hline BE2B2-2 & $\begin{array}{l}\text { Bacillus sp. Bc38(2011) 16S ribosomal RNA } \\
\text { gene. Partial sequence }\end{array}$ & JF772469.1 & 98 \\
\hline BE2B2-5 & $\begin{array}{l}\text { Acinetobacter sp. FZW22 16S ribosomal RNA } \\
\text { gene. Partial sequence }\end{array}$ & KT964806.1 & 97 \\
\hline
\end{tabular}

cendawan patogen. Hal tersebut ditandai dengan memendeknya miselium dan terdapat zona bening antara koloni cendawan patogen dengan bakteri antagonis. Struktur sel pada hifa cendawan patogen uji mengalami malformasi, ditandai dengan lisis sehingga miselium mengecil dan menipis pada bagian ujung.

Metabolit bakteri endofit BE2B2-1, BE2B2-2, dan BE2B2-5 merupakan bakteri yang potensial untuk menghambat pertumbuhan A.flavus. Hal ini dapat disebabkan oleh senyawa metabolit yang dihasilkan oleh 3 bakteri ini lebih kompleks. Hallman dan Berg (2006) melaporkan senyawa metabolit yang dihasilkan bakteri endofit diantaranya pelarut fosfat dan enzim penghidrolisa seperti kitinase, protease, selulase, lipase, dan pektinase. Arios et al. (2014) menyatakan bahwa bakteri endofit yang diisolasi dari tanaman kacang tanah mampu menghambat pertumbuhan cendawan Sclerotium sp. dan mampu meningkatkan tinggi, jumlah daun, dan berat kering kecambah tanaman. Saylendra dan Firnia (2013) melaporkan bahwa bakteri endofit kelompok Bacillus sp. dapat mengendalikan penyakit tanaman jagung dan dapat menginduksi hormon pertumbuhan.

Hasil penelitian ini membuktikan bahwa metabolit bakteri endofit BE2B2-1, BE2B2-2, dan BE2B2-5 yang diisolasi dari jaringan batang kacang tanah memiliki potensi sebagai agens hayati untuk mengendalikan A. flavus pada kacang tanah.

\section{DAFTAR PUSTAKA}

Abidin Z, Aini LQ, Abadi AL. 2015. Pengaruh bakteri Bacillus sp. dan Pseudomonas sp. terhadap pertumbuhan jamur patogen Sclerotium rolfsii Sacc. penyebab penyakit rebah semai pada tanaman kedelai. J HPT. 3(1):1-10.

Arios LN, Suryanto D, Nurtjahja, Munir E. 2014. Asai kemampuan bakteri dari kacang tanah dalam menghambat pertumbuhan Sclerotium sp. pada kecambah kacang tanah. J HPT Tropika. 14(2):178-188.

Barnett HL, Hunter BB. 1998. Illustrated Genera of Imperfect Fungi Fourth Edition. Ed ke-5. Minnesota (US): APS Press.

Dharmaputra OS, Santi A, Retnowati I, Windyarani A. 2013. Kualitas fisik, populasi Aspergillus flavus, dan kandungan aflatoksin B1 pada biji kacang tanah mentah. J Fitopatol Indones. 9(4):99-106. DOI: https://doi.org/10.14692/jfi.9.4.99.

ElitaA, Saryono S, Christine J. 2013. Penentuan waktu optimum produksi antimikroba 
dan uji fitokimia ekstrak kasar fermentasi bakteri endofit Pseudomonas sp. dari umbi tanaman dahlia (Dahlia variabilis). J Indones Chemist Acta. 3(2):56-62.

Hallmann J, Berg G. 2006. Control of plant pathogenic fungi with bacterial endophytes. Di dalam: Schulz BJE, Boyle CJC, Sieber TN, editor. Microbial Root Endophytes. Jerman (EU): Springer.

Hallmann J, Quadt-Hallmann A, Mahaffee W, Kloepper J. 1997. Bacterial endophytes in agricultural crops. Can J Microbiol 43(10):895-914. DOI: https://doi. org/10.1139/m97-131.

Hossain I, Dey P, Dilruba K. 2013. Quality of vegetable seeds collected from mymensingh region in Bangladesh. Int J Appl Sci Biotechnol. 2(1):103-108. doi:10.3126/ijasbt.v2il.9926.

Ibiam, O.F.A. dan Egwu B.N. 2011. Postharvest seed-borne diseases associated with the seeds of three varieties of groundnuts (Arachis hypogaea .L) Nwakara, Kaki, and Campalla. ABREV. 2(4):598602. DOI: https://doi.org/10.5251/ abjna.2011.2.4.598.602.

Ikeda S, Okubo T, Anda M, Nakashita H, Yasuda M, Sato S, Kaneko T, Tabata S, Eda S, Momiyama A, Terasawa K, Mitsui H, Minamisawa K. 2010. Community and genome-based views of plant-associated bacteria: plant-bacterial interactions in soybean and rice. Plant Cell Physio. 51:1398-1410. DOI: https://doi. org/10.1093/pcp/pcq119.

[ISTA] International Seed Testing Asociation. 1996. International Rules for Seed Testing. Seed Sci Technol. 24: 39-42.

Klement Z, Goodman RN. 1967. The hypersensitive reaction to infection by bacterial plant pathogens. Annu Rev Phytopathol. 5(1):17-44. DOI: https://doi.org/10.1146/annurev. py.05.090167.000313.

Munif A, Wiyono S, Suwarno. 2012. Isolasi bakteri endofit asal padi gogo dan potensinya sebagai agens biokontrol dan pemacu pertumbuhan. J Fitopatol Indones. 8(3):57-64. DOI: https://doi.org/10.14692/ jfi.8.3.57.

Saylendra A dan Firnia D. 2013. Bacillus dan Pseudomonas sp. asal endofit akar jagung (Zea mays L.) yang berpotensi sebagai pemacu pertumbuhan tanaman. J Ilmu Pertanian dan Perikanan. 2(1):19-27.

Sukmadi RB. 2013. Aktivitas fitohormon Indole-3-Acetic Acid (IAA) dari beberapa isolat bakteri rhizosfer dan endofit. J Sains dan Teknologi Indones. 14(3):221-227.

Triana Y. 2007. Aplikasi beberapa fungisida nabati dan lama penyimpanan terhadap viabilitas dan vigor benih kakao (Theobrome cacao) [skripsi]. Pekanbaru (ID): Universitas Riau. 